\title{
The Predictive Validity of Mock GCE Advanced Level Biology Scores on GCE Advanced Level Biology Scores: A Case Study of Science High Schools in Fako Division- Buea, Cameroon
}

\author{
Ekwale Emilia Ada \\ M.Ed, PhD in view, Department of Curriculum Studies and Teaching \\ Faculty of Education, University of Buea, Cameroon, Central Africa
}

\begin{abstract}
This study set out to determine the predictive validity of Mock GCE Advanced Level Biology Scores on G.C.E Advanced Level Biology Scores that is, to ascertain whether students who pass in Mock G.C.E also pass in GCE. The target population was the Upper Sixth Science Students in High Schools in Fako Division in the year 2006.
\end{abstract}

The sample of the study was 200 students (92 males and 108 females) who were selected from four Government schools, four Mission schools and two Lay private schools. These schools were mixed sex schools, singles sex schools, boarding schools and day schools. Four hypotheses and four research questions were formulated to guide the research. The hypotheses were:

1) There is no correlation between students score in Mock G.C.E Advanced Level Biology and their scores in G.C.E Advanced Level Biology. That is students who pass in mock G.C.E Advanced Level Biology do not pass in GCE Advanced Level Biology.

2) There is no predictive validity in the correlation of students' scores in mock G.C.E advanced level biology and their scores in G.C.E advanced level biology in Mission, Government and Lay Private schools.

3) There is no predictive validity in the correlation of students' scores in mock G.C.E Advanced Level Biology and their scores in G.C.E Advanced Level Biology in single and mixed sex schools.

4) There is no predictive validity in the correlation of students' scores in mock G.C.E Advanced Level
Biology and their scores in G.C.E Advanced Level Biology in boarding and day schools.

Employing the correlation survey design, scores for mock G.C.E examination were collected from records in the schools and scores for G.C.E examination were collected from the G.C.E Board. Using Mean, Standard Deviation and Pearson Product Moment Correlation coefficient (r), the data were analysed using the SPSS programme. The four null hypotheses were rejected and the alternate ones retained. They indicated that, there is a correlation between mock G.C.E Advanced Level Biology scores and G.C.E Advanced Level Biology scores and that; r-values vary from one type of school to another. Some suggestions and recommendations were made.

KEY WORDS: Predictive validity, Mock G.C.E, GCE, Advanced Level, Biology scores, Science High Schools, Fako Division, Buea, Cameroon

\section{INTRODUCTION}

The standards of education are on the decline, the products of schools cannot fit into the society. This decline in the standard of education can be clearly seen in the past GCE Advanced Level Biology results from1994 to 2007 which had just been lingering around an average percentage of $48.87 \%$. If students are encouraged to be serious with the mock G.C.E examination preparation, it will go a long way to create early awareness in the preparation for GCE Advanced Level Biology and this might increase the $\%$ pass for A Level Biology in the G.C.E. 


\section{BACK GROUND OF THE STUDY}

According to statistics from Cameroon GCE Board, the percentage pass for advanced level from 1994 to 2007 has been $46.87 \%, 48.61 \%, 41.95 \%, 49.45 \%$, $44.71 \%, 53.17 \%, 51.72 \%, 43.87 \%, 47.49 \%$, 44.53\%, $45 \%, 57.74 \%, 53.58 \%$, and $55.58 \%$ respectively. As the percentage pass for advanced level is fluctuating, so the \% pass for A Level Biology is also fluctuating. In GHS Buea, in the year 1998, the percentage pass for advanced level biology was $62.07 \%$ and decreased to $48.21 \%$ in the year 2000 . There was an increase in 2001 with a percentage of $80.18 \%$ and 2002 saw a landslide decrease of $48.5 \%$. There was an increase of $79.5 \%$ in 2003 and $81.08 \%$ in 2004 . It has been noted that the mock percentages are always inferior to those for GCE for all known years and are always fluctuating. Nenty (1985) is in line with this statement.

The age span of students who constitute the population of the study is 15-20 years and they are therefore known as adolescents. Adolescents have characteristics such as physical growth and maturity including sexual maturity and the sense of development of individual identity which involves questions such as "who am I?" and "where am I going to?" and involves deciding what is worth doing and formulating standards of conduct for evaluating one's conduct and that of others (Hilgard, Atkinson and Atkinson, 1979). Adolescents experience role confusion when the views and values of their parents differ from those of their peers and this role confusion can lead to low performance in biology and other subjects. Adolescents are exposed to drug addiction and according to Ornstein and Levine (1989), "the causes for drug addiction among the adolescents are low academic performance, rebelliousness; criminal activity; influence by peers and escape from the demands of preparing for adult life". As adolescents develop physically, their cognitive (intellectual) abilities also develop. As Mbua (1987) puts it, "in the adolescent period, specific motor skills are developed and intellectual growth tends to reach its peak". One will be tempted thus to think that the highest peak of intellectual development can cause high academic performance and achievement but this is not always the case for most of the adolescents since they are distracted by both internal and external factors.

A number of researchers had carried out empirical studies on predictive validity of a particular predictor variable on a criterion variable with the least interval between the two variables was three months and the highest was one year and had high predictive validity; Nolan and Jacobson (1972); Merrit (1972); Nenty (1985); Fraenkel and Wallen (2000) ; Liddell, Lycett and Rae (1997); Ugwuanyi (1991); Denga (1987); Cele and Kwele (2006); Nenty (2006 Musch and Broder (1999); WAEC (2001); Unwadiae and Oke (2006).

\section{PROBLEM STATEMENT}

The standards of education are deteriorating in such a way that, the products of our schools cannot meet up with the demands of the society. Emphasizing on this, (Cubberley, 1934) stated that "the mode of education now adopted and the branches of knowledge that are taught at our English Grammar schools, are not sufficiently extensive nor otherwise calculated to bring the powers of the mind into operation nor to qualify a youth to fill usefully and respectably many of those stations both public and private in which he may be placed". Many students graduate from high school with inadequate reading, writing and mathematics skills, as such, some go to college and have to enroll in remediation classes, others drop out of school and do not have the skills that will enable them to advance in the work world (Santrock, 2004)

The percentage of students who pass the G.C.E is fluctuating as seen in the statistics of G.C.E Advanced Level from the G.C.E Board and in GCE Advanced Level biology specifically from 1998-2006 of GHS Buea as stated in the background. In all the years mentioned above, there was only one "A" grade in 2003 in advanced level biology in GHS Buea. This fluctuation is evident in most schools in Fako Division and the nation at large. The low academic achievement has generated much controversy among teachers and other educators, parents and the ministry of Secondary Education. Parents shift the blame to teachers and the government; teachers blame parents and students, while the Government blames teachers as responsible for the falling standards of education.

Every mock G.C.E examination in a particular subject is a replica of the G.C.E examination itself due to the fact that the two exams are structured on the same syllabus. Therefore advanced level biology mock G.C.E examination is a replica of advanced level G.C.E biology examination. One of the tenets of classical conditioning is generalization. Generalization is when a new stimulus similar to the original condition stimulus has a tendency to produce 
a similar response (Jones, Kemenes and Benjamin, 2001). The original conditioned stimulus is advanced level mock G.C.E examination, the new stimulus is advanced level biology G.C.E examination and the two similar responses are scores in advanced level biology mock G.C.E examinations and scores in advanced level biology G.C.E examination. From this theory, it can be assumed that, performance in mock G.C.E might foster performance in G.C.E. Mock G.C.E examination is not taken seriously by teachers, students and parents. There is a great controversy among some educationists concerning mock GCE examinations. The N.P. Is (National Pedagogic Advisers), R.P.Is (Regional Pedagogic Advisers) and principals of colleges say mock is indispensable in the academic achievement of students, parents and the students deny the importance of mock examination and say it is a waste of time. The minister of Secondary Education and the delegates of secondary education say mock G.C.E examinations should be controlled by schools. Some teachers say mock G.C.E examination is important and should be controlled by R.P.Is and N.P.Is yet others cry aloud that it should be stopped. Some teachers' mark their students mock papers only on topics they have taught thus diluting the strength of the mock examination. The peak of this educational tug of war was seen when students of GBHS Molyko rioted in 2005 that the monies they paid for mock examination should be refunded to them. In 2006, the students of GBHS Tiko rioted and in 2007, those of GBHS Muea rioted for the same reason. This is indeed a problem that needs to be redressed very fast. Studies like this and many others, may give some evidence of the importance of mock examinations which will go a long way to end this educational tug of war.

\section{THEORIES}

\section{Piaget (1952) Theory of Cognitive Development}

Piaget (1952) stated that assimilation (when a child incorporates new knowledge into existing knowledge) and accommodation (when a child adjusts to new information) are processes responsible for how children use and adopt their schemas. He also contended that children make sense out of their world by cognitively organizing their experiences. From the above statements, a student who can incorporate new knowledge into existing knowledge, adjust to new information and is able to group isolated facts into a single useful higher order information will be able to achieve higher and therefore pass his/her examinations be them mock GCE or GCE. A student who cannot assimilate and accommodate will perform poorly. Neo Piagetians like Case (2000), revised Piaget's theory but laid more emphasis on how children process information through attention, memory and using strategies. From this, a student who is not attentive in class, is always distracted, cannot remember learnt facts and does not use different study strategies, will perform poorly.

\section{Wolfgang Kohler's Theory of Insight}

Chauthan (1987) describes the cognitive theory of Wolfgang Kohler the German gestalt psychologist as the theory of insight. According to Gestalt psychology, the individual and his environment form a psychological field, insight is the perception of the field and insight gradually restructure the psychological field. To Kohler, an individual (animal) must perceive the total problem before insight can occur in solving the problem. Gestalt theories also emphasize on the experiential background and interest of learners. Information from the above theory reveal that, in examination conditions, a student must understand the questions and their subparts very well before insight or ideas are elicited which will be used to answer the questions and enable the student to pass his/her examinations. Without understanding the questions, insight will not be elicited and the student will fail his/her examinations. A student will perform better in any task that is related to something he/she had experienced before. On the other hand, he/she will perform less in any task that is not related to something he/she had experienced before. A student who is interested in a subject performs better than one who is not interested in that subject.

\section{Vygotsky's Social Constructivist Theory}

In the social constructivist theory of Vygotsky, he argued that, the most important tool that shapes cognitive functioning is language (Robbins, 2001). His theory also emphasis that, knowledge is situated and collaborative (Bearison and Dorval, 2002) and Maynard (2001). This suggests that knowing can best be advanced through interactions with others in cooperative or group activities. From Vygotsky's theory, we can rightly infer that without good language expression, a student cannot pass his or her examinations be them mock G.C.E or G.C.E itself because the ideas he/she has cannot be expressed due to lack of proper language development. This is because language is used to express ideas in all other 
subjects. The fact that language is indispensable, in the academic achievement of students cannot be overemphasized. Vygotsky's believe in cooperative learning can seen when students study in groups and gain new ideas from others. It is also seen in biology practicals where most often students are grouped to perform experiments. Through this, the students learned psychomotor skills and other skills from their peers and from the demonstration acts of the teacher.

\section{Bandura's Observational Learning Theory}

In Bandura (1965) and Bandura (2000), where Bandura's observational learning theory or imitation or modeling theory was expressed, he emphasized on the learning process in which a person observes and imitates someone else's behavior. For the observation to appropriately take place there must be attention, retention, production and motivation. In fact, this theory is indispensable to practical work in biology in which students observe a biology teacher who is demonstrating how an experiment is performed by being attentive, retentive and retaining what has been observed. After sometime, the students are asked to perform the experiments so they follow the steps of the teacher chronologically. This theory also indicates that, a student who is attentive in class and is not distracted, understands the teacher better and achieves higher than those students who are always distracted in class.

\section{Atkinson and Shiffrin's (1968) Theory of Memory}

Atkinson and Schifrin's (1968) theory of memory states that sensory input goes into sensory memory (SM) and due to the process of attention, information moves into the short term memory (STM) where it remains for 30 seconds or less unless it is rehearsed and sent into the LTM (long term memory) storage. From the long term memory storage information can be retrieved and be sent into the short term memory before it can be used for some purpose e.g. examination. A student therefore who is attentive in class and reads well at home, sends information to his/her short term memory but this information need to be rehearsed by frequent revision in order to be transferred into the long term memory where it can be retrieved easily for particular purpose e.g. examination. Such a student will achieve higher than those who do not rehearse or revise their materials before examinations.

\section{Classical Conditioning Theory by Ivan Pavlov}

Classical conditioning was propounded by Ivan Pavlov. The three main tenets of classical conditioning are generalization, discrimination and extinction. Generalization is when a new stimulus similar to the original conditioned stimulus has a tendency to produce a similar response (Jones, Kemenes and Benjamin, 2001). This is related to this topic in that, a student who passes in mock biology, will be very serious when preparing for biology examination in G.C.E and will end up causing the student to pass his G.C.E biology examination because mock biology is similar to G.C.E biology.

\section{Operant Conditioning by E.L Thorndike and B.F skinner}

The proponents of operant conditioning are E.L Thorndike and B.F skinner. Thorndike's law of effect states that behaviors followed by positive outcomes are strengthened while those followed by negative outcomes are weakened. The main ideas in Skinner's theory are reinforcement and punishment. Punishment is a consequence that decreases that probability that a behavior will occur. Reinforcement is divided into positive reinforcement in which the frequency of a response increases because it is followed by removal of an aversive or unpleasant stimulus. This theory is related to this research work in that, a student who fails mock GCE examination and is scolded by the teacher for his failure will work harder to pass the next examination because the scolding may act as punishment and decrease the probability of the occurrence of the failure in such a way that the student may end up passing GCE though he failed mock GCE. Positive reinforcement can be seen when a student passes for example in mock biology and the teacher congratulates the student, and the student passed very well in GCE biology with a high score. Negative reinforcement is when the frequency of a response increases due to the fact that it is followed by the removal of an unpleasant stimulus (Frieman, 2002). For example a student finds it difficult to study biology and fails his mock examination so his/her teacher keeps nagging and finally, the student gets tired of hearing the nagging and starts studying hard. The student's response (studying hard) removed the unpleasant stimulus (nagging) and this will help the student to pass his G.C.E examinations. 


\section{Abraham Maslow's theory of self-actualization}

In Abraham Maslow's theory of self-actualization, he classified needs hierarchically into physiological needs which are air, hunger, thirst, sleep etc; safety needs which are ensuring survival such as protection from crime and war; love and belonging needs such as security, affection and attention from others; self esteem needs which involves feeling good about ourselves; and self actualization needs where our potentials are realized. The physiological needs were the lower needs while the self-actualized needs were the highest needs. Maslow believed that, the lower needs must first be satisfied and that, the needs can be satisfied in the above sequence. if a student's lower order needs like physiological, safety needs etc are not satisfied that student will have low achievement in school because he/she may not be attentive in class. On the other hand, a student whose lower order needs are satisfied, will be able to be attentive in class and concentrate on his/her studies with no distractions and achieve higher by passing his examinations. Some critics criticized Maslow's ordering of needs and argue that, the needs exist but must not follow the sequence proposed by Maslow. According to Santrock (2004), some students' cognitive needs might be more fundamental than esteem needs and some other students might meet their cognitive needs though they have not experienced love and belongingness. The fact that without physiological needs, a student cannot meet up with his/her higher order needs cannot be overemphasized as such, a student who is hungry and feeling sleepy cannot be attentive in class and this can affect the students achievement. Murray (1938) theorized that "unsatisfied needs would arouse the person to work that would be sustained until satisfaction has been attained" and Chauthan (1987) describes hull's theory as the drive-reduction theory of reinforcement in which he emphasized that, the need of an individual is often said to motivate or drive the associated behavior or activity. From these theories, it can be inferred that, enthusiastic students always have the need to aspire and achieve. McClelland (1961) and (1964) stated that "pupils who work diligently to earn high grades have successful experiences reaching specific goals they set for themselves and that those who lack the need for achievement have had experiences with failure or have set unrealistic goals".

\section{Blooms Taxonomy of Cognitive Objectives}

Blooms taxonomy was developed by Benjamin Bloom and his colleagues in 1956. This theory classifies educational objectives into three domains: cognitive, affective and psychomotor. The cognitive domain is made up of Knowledge, Comprehension (low-level objectives), Application, Analysis, Synthesis and Evaluation (high level objectives). Teachers, who pose examination questions involving only the low-level cognitive processes, leaving out the high level cognitive processes, will cause poor development of critical thinking, problem solving and creativity abilities of students. These students will always face difficulties in public examinations like G.C.E. Teachers who administer tests that contain objectives from the cognitive domain and not in the affective and psychomotor domain, restrict the development of a varied number of skills in students. Santrock (2004) in line with this assertion emphasized that "in the past teachers have generally focused on cognitive or behavioral objectives". Recently, Anderson and Krathwohl (2001) updated the knowledge dimension of bloom to include four categories, which are factual knowledge (knowledge of basic elements), conceptual knowledge (the interrelationships among the basic elements), procedural knowledge (how to do something) and Meta cognition (knowledge of strategies of remembering). This is in line with the way advanced level G.C.E is handled. Paper one and two of Advanced Level biology involve all the levels of the cognitive domain, the affective domain and the factual/conceptual knowledge while paper 3 involves the psychomotor domain and procedural knowledge.

\section{Methodology}

\section{Research Design}

The design of the study was a correlation research design. The researcher collected mock G.C.E examination scores from various schools and the G.C.E scores from the Cameroon G.C.E Board. The mock G.C.E examination was written in March 2006 and the G.C.E examination was written in June 2006. The time interval between the two examinations was two months.

The correlation research design was the most appropriate in this study because the study was predictive and therefore two sets of scores from the same individuals were correlated. 


\section{Target Population}

The population of this study was made up of upper sixth science students who offered biology in high schools in Fako division in the year 2006. Fako division has four subdivisions, which are Buea subdivision, Limbe subdivision, Muyuka subdivision and Tiko subdivision. There were 19 schools in Fako division, which offered biology in upper sixth science in the year 2006. The schools were Government, Mission and Lay Private schools. The population size of the study taken from these schools in Fako division in the year 2006 was 1000 students.

\section{Sample of the Study}

The schools from which the sample was obtained were 10 schools out of the 19 schools in Fako division that offered A Level biology in 2006. The sample was 200 students. The schools were Saint Joseph's College Sasse Buea, Baptist High School Soppo Buea, Salvation Bilingual High School Molyko-Buea, Government High School Buea, Saker Baptist High School Limbe, Government Bilingual High School Muyuka, Christ the King College Tiko, Government Bilingual High School Tiko and Imperial Academy of Arts and Science Tiko.

\section{Sampling Technique}

The ten schools were selected through the purposeful sampling. Purposive sampling is a type of sampling in which the researcher uses his or her judgment to select a sample he/she believes based on prior information will provide the information he or she needs (Fraenkel and Wallen 2006). The reason why purposive sampling was used to select the schools was that, the researcher wanted schools from all the four subdivisions of the Fako division to be represented and that single sex and mixed sex schools owned and managed by the Government, the Mission and the Private sector should also be represented. Another reason was that, some of the schools were left out so that, only those with G.C.E centre numbers were selected to ease the collection of G.C.E scores.

The 200 students were selected from the 10 schools through the stratified random sampling technique. It is a sampling technique in which certain subgroups or strata are selected for the sample in the same proportion as they exist in the population. The researcher believes that gender is an important extraneous variable that may affect the outcomes of the study, so she decided to ensure that, the proportion of males and females in the population is the same in the sample. The researcher used these steps in her sampling process: She identified the target population which was 1000 students; she found out that there were 540 females and 460 males. She decided to have a sample made up of $20 \%$ of the target population; she randomly selected $20 \%$ from each stratum (group) of the population. This resulted to 108 females (i.e. $20 \%$ of 540 ) and 92 males (i.e. $20 \%$ of 460 ) students selected from the subgroups.

\section{Distribution of Sample by School}

\begin{tabular}{|c|c|c|c|c|}
\hline \multirow[t]{2}{*}{ School } & \multirow[t]{2}{*}{ Abbreviation } & \multicolumn{3}{|c|}{ No Sampled } \\
\hline & & $\mathbf{M}$ & $\mathbf{F}$ & $\mathbf{T}$ \\
\hline Saint Joseph's College Sasse Buea & $\mathrm{SJC}-3$ & 20 & - & 20 \\
\hline Baptist High School Soppo Buea & $\mathrm{BHS}$ & 10 & 10 & 20 \\
\hline Salvation Bilingual High School Buea & SBHS & 10 & 10 & 10 \\
\hline Government High School Buea & GHS & 06 & 14 & 20 \\
\hline Saker Baptist High School Limbe & SBHS & - & 20 & 20 \\
\hline Imperial Academy of Arts and Science Tiko & IMPAAS & 10 & 10 & 20 \\
\hline Government Bilingual High School Limbe & GBHS & 06 & 14 & 20 \\
\hline Government Bilingual High School Muyuka & GBHS & 10 & 10 & 20 \\
\hline Christ the King College Tiko & $\mathrm{CKC}$ & 10 & 10 & 20 \\
\hline Government Bilingual High School Tiko & GBHS & 10 & 10 & 20 \\
\hline Total & & 92 & 108 & 200 \\
\hline
\end{tabular}

Table 1: show a sample of 20 students in each school that was selected .The total number of students of students sampled in the 10 schools was 200 (92 males and 108 females). This is for hypothesis 1 
International Journal of Trend in Scientific Research and Development (IJTSRD) ISSN: 2456-6470

Distribution of Sample by Type of School

\begin{tabular}{|l|l|l|l|l|}
\hline \multirow{2}{*}{ School } & \multicolumn{2}{c|}{ Abbreviation } & \multicolumn{3}{c|}{ No Sampled } \\
\cline { 3 - 5 } & & \multicolumn{2}{c|}{ M } & \multicolumn{1}{c|}{ F } \\
\hline Government schools & GS & 32 & 48 & 80 \\
\hline Mission schools & MS & 40 & 40 & 80 \\
\hline Lay Private schools & LPS & 20 & 20 & 40 \\
\hline TOTAL & & $\mathbf{9 2}$ & $\mathbf{1 0 8}$ & $\mathbf{2 0 0}$ \\
\hline
\end{tabular}

Table 2: show the number of males and females sampled in Government, Mission, and Lay Private Schools. The total number of students sampled in Government Schools was 80 (32 males and 48 females); in Mission schools, it was 80 students (40 males and 40 females), and in Lay Private schools, it was 40 students (20 males and 20 females). This is for hypothesis 2.

Distribution of sample by the type of school e.g. single sex and mixed schools.

\begin{tabular}{|l|l|l|l|l|}
\hline \multirow{2}{*}{ School } & \multicolumn{2}{c|}{ Abbreviation } & \multicolumn{3}{c|}{ No sampled $^{-1}$} \\
\cline { 3 - 5 } & & \multicolumn{2}{c|}{ M } & \multicolumn{1}{c|}{ F } \\
\hline Mixed Sex Schools & MSS & 72 & 88 & 160 \\
\hline Single Sex Schools & SSS & 20 & 20 & 40 \\
\hline Total & $\mathbf{9 2}$ & $\mathbf{1 0 8}$ & $\mathbf{2 0 0}$ \\
\hline
\end{tabular}

Table 3: shows the number of males and females sampled in mixed sex schools and single schools. 160 mixed sex school students were sampled (72 males and 88 females. in single sex schools, 40 students were sampled (20 males and 20 females). this is for hypothesis 3.

Distribution of Sample by Students Status e.g. Day Schools and Boarding Schools.

\begin{tabular}{|l|l|l|l|l|}
\hline \multirow{2}{*}{ Type School } & \multicolumn{2}{c|}{ Abbreviation } & \multicolumn{3}{c|}{ No Sampled $^{-1}$} \\
\cline { 3 - 5 } & & \multicolumn{2}{c|}{ M } & \multicolumn{1}{c|}{ T } \\
\hline Day Schools & DS & 52 & 68 & 120 \\
\hline Boarding Schools & BS & 40 & 40 & 80 \\
\hline TOTAL & $\mathbf{9 2}$ & $\mathbf{1 0 8}$ & $\mathbf{2 0 0}$ \\
\hline
\end{tabular}

Table 4: Shows the number of males and females sampled in day schools and boarding schools. 120 day school students were sampled (52 males and 68 females), 80 boarding school students were sampled (40 females and 40 males). This is for hypothesis 4 .

\section{Instrumentation}

This study was a quantitative study and made use of G.C.E Advanced Level biology scores and mock scores obtained from records in schools and G.C.E Board respectively. Mock examination was written in March 2006 while the G.C.E examination was written in June 2006. The Interval between the two examinations was two months.

\section{Validation of Data Collected}

As the researcher visited a school and presented her attestation of research, the class list with students' names was presented to her. To make sure mock
G.C.E scores were those of the year 2006, the researcher looked at the paper to see if the title was mock G.C.E advanced level biology scores for 2006. The researcher copied the name of each student and his or her mock G.C.E score. The researcher was also given the scores for GCE advanced level biology at the GCE Board and made sure that each student's G.C.E score was written against his or her name. From this, the researcher was sure that each mock G.C.E score and G.C.E score were the real scores of each student. The researcher refused a list of mock and GCE scores without names to match them. 


\section{Reliability of Data Collected}

After collecting the mock G.C.E scores and G.C.E scores from the schools, the researcher went to the office of the Regional Pedagogic Inspector for biology and collected the list of students and their mock scores to compare with the ones from the schools to make sure they were the same. The researcher went to the G.C.E Board and collected G.C.E scores for various schools to make sure G.C.E scores collected from the schools reflected the scores collected from the G.C.E Board. This was to ensure reliability. After the mock G.C.E and G.C.E scores were collected, the researcher erased the names of the students to ensure confidentiality.

In another way to ensure the reliability of the study, the researcher collected 10 mock G.C.E advanced levels biology scores and 10 G.C.E advanced level biology scores of the same students from one Government school (GHS Buea), one mission school (BHS Buea) and one Lay Private school (Salvation Bilingual High School Molyko Buea) in the years 2004 and 2005. The scores of the year 2004 after computation using Pearson Product Moment Correlation Coefficient resulted in an r-calculated value of 0.545 which if compared to the r-critical values at 0.05 and 0.01 levels of significance 0.355 and 0.456 respectively, showed that there is a correlation between the mock G.C.E scores and G.C.E in advanced level biology. The scores of the year 2005 also revealed that, there is a correlation between mock G.C.E advanced level biology scores because the r-calculated value 0.510 was greater as compared to the r-critical values at 0.05 and 0.01 levels of significance 0.355 and 0.456 respectively.

\section{Method of Data Collection}

After selecting the schools from which the sample had to be obtained, the researcher went to each school and presented herself to the principal and showed him/her the attestation of research that was obtained from the faculty of education. The principals of the Government and Lay Private schools sent the researcher to the vice principals while those of the Mission schools, sent the researcher to the Deans of Studies. In the offices of the deans of studies and vice principals, the researcher presented the attestation of research and the lists of students and their mock G.C.E scores were given to the researcher. The researcher copied the names of students and their mock scores. The researcher also noted the centre names and numbers for the various schools. In some of the schools, the researcher could collect the G.C.E grades which were converted into scores and linked them to the mock G.C.E scores already collected. Some of the schools did not have the GCE grades so the researcher went to the GCE board and presented her attestation of research. She was asked to write an application to the registrar with a photocopy of the attestation of research. The registrar accepted the application, signed it and sent it to the mail office. From the mail office it was sent to the authorities concerned with G.C.E scores and as such the researcher was given the GCE scores. In some of the schools, the mock G.C.E scores were not available so the researcher used the mock GCE grades and converted them into scores using the Cameroon GCE advanced level grading system. At the end, in each of the 10 schools, the researcher had the mock G.C.E and G.C.E scores of each student that constituted the sample. Before going to each school, the researcher knew the number of males and females to the sampled. At the end of the exercise, the students' names were wiped to ensure confidentiality.

\section{Method of Data Analysis}

The mock scores collected from various schools and the G.C.E scores collected from the G.C.E Board which were originally on $100 \%$ were all converted to scores on 20 to the nearest round figure.

Data analysis was subjected to both descriptive and inferential statistics. For descriptive statistics, means and standard deviations were used. For inferential statistics, the Pearson Product Moment Correlation Coefficient was computed. All the analyses were done using the Special Package for Social Science (SPSS). The predictive validity was achieved by comparing the $r$ calculated values for the different types of schools and interpretation made on the results.

Where r-calculated value is greater that $r$-critical value, the null hypothesis is rejected and the alternative hypothesis retained. Where r-calculated value is lesser that $r$-critical value, the null hypothesis was retained and the alternative hypothesis rejected. The magnitude of the relationship is determined by the following range.

$0-0.44=$ low relationship; $0.45-0.55=$ moderate relationship and $0.56-1.00=$ high relationship. 


\section{FINDINGS}

\section{Hypothesis 1.}

Ho: There is no predictive validity of students' score in mock GCE advanced level biology and their scores in GCE advanced level biology or students who pass in mock GCE advanced level biology do not pass in GCE advanced level biology.

Ha: There is a predictive validity of students' scores in mock GCE Advanced Level biology and their scores in GCE advanced level biology or students who pass in mock GCE advanced level biology also pass in GCE advanced level biology.

\section{Presentation of means and standard deviations for} mock GCE examination results in advanced Level biology and GCE examination results in advanced level biology.

\begin{tabular}{|l|l|l|l|l|}
\hline $\begin{array}{l}\text { Type of } \\
\text { exam }\end{array}$ & $\mathbf{N}$ & $\begin{array}{l}\text { Degree of } \\
\text { freedom } \\
\text { (f) }\end{array}$ & Mean & Standard \\
\hline Mock & 200 & 198 & 7.78 & 2.62 \\
\hline GCE & 200 & 198 & 10.14 & 2.86 \\
\hline
\end{tabular}

Table 5: Shows that the mean at the mock G.C.E examination is 7.78 while that at the G.C.E examination is 10.14 this indicates that students perform better at the GCE examination in biology than at the mock GCE examination. The standard deviations are 2.62 and 2.86 respectively for mock GCE and GCE examinations.

\section{Presentation of Pearson Product Moment Correlation Coefficient}

\begin{tabular}{|l|l|l|l|l|}
\hline $\begin{array}{l}\mathrm{r}- \\
\text { calculated } \\
\text { value }\end{array}$ & $\mathbf{N}$ & $\begin{array}{l}\text { degree of } \\
\text { freedom } \\
(\mathrm{f})\end{array}$ & $\begin{array}{l}\mathrm{r}- \\
\text { critical } \\
\text { value at } \\
0.05 \propto- \\
\text { level }\end{array}$ & $\begin{array}{l}\text { r- } \\
\text { critical } \\
\text { value at } \\
0.01 \propto- \\
0.01\end{array}$ \\
\hline 0.497 & 200 & 198 & 0.138 & 0.181 \\
\hline
\end{tabular}

Table 6: Shows that, r-calculated value $(0.497)$ is greater than r-critical value $(0.138)$ at 0.05 alpha level of significance. At 0.01 alpha level of significance, rcalculated value (0.497) is greater than $r$-critical value (0.181). This implies that at both alpha levels of significance, r-calculated value is greater than rcritical value therefore the scores are significantly related. We reject the null hypothesis (Ho) following the decision rule. Inference made, leads us to conclude that, performance at the mock GCE examination in biology is significantly correlated to performance at the GCE examination in biology. Since $0.45<0.497<0.55$ the magnitude is moderate in a positive direction. This implies that performance at the mock GCE examination in advanced level biology is moderately correlated to performance at the GCE advanced level examination. Where there is a good pass at the mock GCE examination, it is more likely to produce a good pass at the GCE examination in biology. Where there is a failed score in mock GCE advanced level biology, it is more likely to produce a failed score at the GCE examination in biology.

It can therefore be concluded that, the predictive validity of mock GCE advanced level biology scores on GCE advanced level biology scores is moderate with an $r$ value of 0.497 .

\section{Hypothesis 2}

Ho: There is no predictive validity in the correlation of students' scores in mock GCE advanced level biology and their scores in GCE advanced level biology in Mission, Government and Lay Private Schools.

Ha: There is a predictive validity in the correlation of students' scores in mock GCE advanced level biology and their scores in GCE advanced level biology in Mission, Government and Lay Private schools.

Presentation of means and standard deviations for mock GCE and GCE advanced level biology for the three types of schools.

\begin{tabular}{|l|l|l|l|l|}
\hline School type & $\begin{array}{l}\text { Mean } \\
\text { for } \\
\text { mock } \\
\text { exam }\end{array}$ & $\begin{array}{l}\text { Mean } \\
\text { for } \\
\text { G.C.E } \\
\text { exam }\end{array}$ & $\begin{array}{l}\text { standard } \\
\text { deviation } \\
\text { for Mock }\end{array}$ & $\begin{array}{l}\text { Standard } \\
\text { Deviation } \\
\text { for G.C.E }\end{array}$ \\
\hline $\begin{array}{l}\text { Mission } \\
\text { schools }\end{array}$ & 8.35 & 11.47 & 2.117 & 2.216 \\
\hline $\begin{array}{l}\text { Government } \\
\text { Schools }\end{array}$ & 7.1 & 10.09 & 2.84 & 2.53 \\
\hline $\begin{array}{l}\text { Lay Private } \\
\text { schools }\end{array}$ & 7.9 & 7.63 & 2.86 & 2.94 \\
\hline
\end{tabular}

Table 7: Shows that the mean for the G.C.E examination in Mission schools (11.47) is better than the mean for the mock G.C.E examination (8.35). For Government schools, the mean for the G.C.E 
examination (10.09) is better than the mean for mock GCE examination (7.1). For Lay Private schools, the mean for the GCE examination (7.63) is lower than the mean for mock examination (7.9). This shows that, students perform better in Mission schools than in Government and Lay Private schools in both mock GCE and GCE examinations. Performance in GCE is better than in mock GCE for Government and Mission schools except for the Lay Private schools in which students' performance in mock GCE is better than that for GCE.

\section{Performance of Pearson Product Moment Correlation Coefficient values (r) and critical}

Values for the three types of schools.

\begin{tabular}{|l|l|l|l|l|l|}
\hline $\begin{array}{l}\text { School } \\
\text { type }\end{array}$ & N & $\begin{array}{l}\text { degree } \\
\text { of } \\
\text { freedo } \\
\mathrm{m}(\mathrm{f})\end{array}$ & $\begin{array}{l}\mathrm{r}- \\
\text { calculate } \\
\mathrm{d} \text { value }\end{array}$ & $\begin{array}{l}\mathrm{r}- \\
\text { critica } \\
\mathrm{l} \\
\text { value } \\
\text { at } \\
0.05\end{array}$ & $\begin{array}{l}\mathrm{r} \text { - } \\
\text { critica } \\
\text { value } \\
\text { at } \\
0.01\end{array}$ \\
\hline $\begin{array}{l}\text { Mission } \\
\text { schools }\end{array}$ & 80 & 78 & 0.714 & 0.220 & 0.287 \\
\hline $\begin{array}{l}\text { Governm } \\
\text { ent } \\
\text { schools }\end{array}$ & 80 & 78 & 0.566 & 0.220 & 0.287 \\
\hline $\begin{array}{l}\text { Lay } \\
\text { Private } \\
\text { schools }\end{array}$ & 40 & 38 & 0.429 & 0.312 & $\begin{array}{l}0.403 \\
\text { lnter }\end{array}$ \\
\hline
\end{tabular}

Table 8: This table shows that r-calculated values for Mission schools (0.714), Government schools (0.566) and Lay Private schools (0.429) are respectively greater than their critical values of $0.220,0.220$ and 0.312 at 0.05 alpha level of significance and 0.287 , 0.287 and 0.403 at 0.01 alpha level of significance. This implies that, performance at the mock examination in biology is significantly correlated to performance at the GCE examination in all three types of schools.

\section{Hypothesis 3}

Ho: There is no predictive validity in the correlation of students' scores in mock GCE advanced level biology and their scores in GCE advanced level biology in single sex schools and mixed sex schools.

Ha: There is a predictive validity in the correlation of students' scores in mock GCE advanced level biology and their scores in GCE advanced level biology in single sex schools and mixed schools.

Presentation of means and standard deviations on performance in mock examination in biology and GCE examination in biology for mixed and single sex schools

\begin{tabular}{|c|c|c|c|c|c|c|}
\hline $\begin{array}{l}\text { Types } \\
\text { of } \\
\text { school } \\
\text { s }\end{array}$ & $\mathrm{N}$ & Df & $\begin{array}{l}\text { Mea } \\
\text { n for } \\
\text { moc } \\
k\end{array}$ & $\begin{array}{l}\text { Mea } \\
n \text { for } \\
\text { GCE }\end{array}$ & $\begin{array}{l}\text { Standar } \\
\mathrm{d} \\
\text { Deviatio } \\
\mathrm{n} \text { for } \\
\text { mock }\end{array}$ & $\begin{array}{l}\text { Standar } \\
\mathrm{d} \\
\text { Deviatio } \\
\mathrm{n} \text { for } \\
\text { GCE }\end{array}$ \\
\hline $\begin{array}{l}\text { Mixed } \\
\text { sex } \\
\text { school } \\
\text { s }\end{array}$ & $\begin{array}{l}16 \\
0\end{array}$ & $\begin{array}{l}15 \\
8\end{array}$ & 7.76 & 9.79 & 2.87 & 2.88 \\
\hline $\begin{array}{l}\text { Single } \\
\text { sex } \\
\text { school } \\
\text { S }\end{array}$ & 40 & 38 & 7.88 & $\begin{array}{l}11.6 \\
5\end{array}$ & 1.32 & 2.11 \\
\hline
\end{tabular}

Table 9: The results presented in this table show that in the two school types, performance at the GCE is better than performance at the mock examination. Single sex schools perform significantly better at the GCE examination with a mean of (11.65) than mixed sex schools with a mean of (9.79). The values for the standard deviation for both examinations in the two school types is high, indicating that most of the scores for mock GCE examinations are not close to the mean.

Performance of Pearson Product Moment Correlation Coefficient values (r) and critical

Values for the two types of schools.

\begin{tabular}{|l|l|l|l|l|l|}
\hline $\begin{array}{l}\text { School } \\
\text { type }\end{array}$ & $\mathrm{N}$ & $\begin{array}{l}\text { Degree } \\
\text { of } \\
\text { freedo } \\
\mathrm{m}(\mathrm{f})\end{array}$ & $\begin{array}{l}\mathrm{r}- \\
\text { calculate } \\
\text { d value }\end{array}$ & $\begin{array}{l}\mathrm{r}- \\
\text { critica } \\
\text { 1 value } \\
\text { at } 0.05\end{array}$ & $\begin{array}{l}\mathrm{r}- \\
\text { critica } \\
\text { 1 value } \\
\text { at } 0.01\end{array}$ \\
\hline $\begin{array}{l}\text { Mixed } \\
\text { sex } \\
\text { school } \\
\text { s }\end{array}$ & $\begin{array}{l}16 \\
0\end{array}$ & 158 & 0.333 & 0.138 & 0.181 \\
\hline $\begin{array}{l}\text { Single } \\
\text { sex } \\
\text { school } \\
\mathrm{s}\end{array}$ & 40 & 38 & 0.525 & 0.312 & 0.403 \\
\hline
\end{tabular}

Table 10: Shows that $r$-calculated value for mixed sex schools $(0.333)$ is greater than $r$-critical value 0.138 at 
0.05 and 0.181 at 0.01 alpha level of significance, $r$ calculated value for single sex schools $(0.525)$ is greater than r-critical value 0.525 at 0.55 and 0.312 at 0.01 alpha levels of significance. This implies that, performance at the mock GCE examination is significantly correlated to performance at the GCE examination in mixed sex schools. The same results are applicable for single sex schools at both levels of significance.

\section{Hypothesis 4}

Ho: There is no predictive validity in the correlation of students' scores in mock GCE advanced level biology and their scores in GCE advanced level biology in boarding schools and day schools.

Ha: There is a predictive validity in the correlation of students' scores in mock GCE advanced level biology and their scores in GCE advanced level biology in boarding schools.

Presentation of means and standard deviations on performance in mock GCE and GCE advanced level biology examinations for boarding and day schools

\begin{tabular}{|l|l|l|l|l|l|l|}
\hline $\begin{array}{l}\text { Types of } \\
\text { school }\end{array}$ & $\mathrm{N}$ & Df & \multicolumn{3}{|c|}{} & \multicolumn{2}{|c|}{$\begin{array}{l}\text { Standard } \\
\text { Deviation }\end{array}$} \\
\cline { 4 - 7 } & & & Moans & GCE & Mock & GCE \\
\hline $\begin{array}{l}\text { Boarding } \\
\text { schools }\end{array}$ & 80 & 78 & 8.35 & 11.47 & 2.11 & 2.22 \\
\hline $\begin{array}{l}\text { Day } \\
\text { schools }\end{array}$ & 120 & 118 & 7.37 & 9.30 & 2.86 & 2.90 \\
\hline
\end{tabular}

Table 11: Shows that, in both boarding and day schools, performance at the GCE examination is better than performance at the mock examinations. The standard deviations are large indicating that, the scores are not close to the means. Performance in both examinations is higher in boarding schools than in day schools.

\section{Presentation of Pearson Product Moment Correlation Coefficient values (r) and critical}

\begin{tabular}{|c|c|c|c|c|c|}
\hline $\begin{array}{l}\text { School } \\
\text { type }\end{array}$ & $\mathrm{N}$ & $\begin{array}{l}\text { Degree } \\
\text { of } \\
\text { freedo } \\
m(f)\end{array}$ & $\begin{array}{l}\text { r- } \\
\text { calculate } \\
\text { d value }\end{array}$ & $\begin{array}{l}\mathrm{r}- \\
\text { critica } \\
1 \\
\text { value } \\
\text { at } \\
0.05\end{array}$ & $\begin{array}{l}\mathrm{r}- \\
\text { critica } \\
1 \\
\text { value } \\
\text { at } \\
0.01\end{array}$ \\
\hline $\begin{array}{l}\text { Boardin } \\
\mathrm{g} \\
\text { schools }\end{array}$ & 80 & 78 & 0.570 & 0.220 & 0.287 \\
\hline $\begin{array}{l}\text { Day } \\
\text { schools }\end{array}$ & $\begin{array}{l}12 \\
0\end{array}$ & 118 & 0.425 & 0.138 & 0.181 \\
\hline
\end{tabular}

Table 12: Shows that, r-calculated value for boarding schools $(0.570)$ is greater than r-critical value 0.220 at 0.05 and 0.287 at 0.01 alpha level of significance. rCalculated value for day schools $(0.425)$ is greater than r-critical value 0.138 at 0.05 and 0.181 at 0.01 alpha levels of significance. This implies that, performance at the mock GCE examination is significantly correlated to performance at the GCE examination in all the two types of schools.

\section{Summary of Findings}

1) There is a correlation between students' score in Mock G.C.E Advanced Level Biology and their scores in G.C.E Advanced Level Biology. That is students who pass in mock G.C.E Advanced Level Biology do not pass in GCE Advanced Level Biology.

2) There is a predictive validity in the correlation of students' scores in mock G.C.E advanced level biology and their scores in G.C.E advanced level biology in Mission, Government and Lay Private schools.

3) There is a predictive validity in the correlation of students' scores in mock G.C.E Advanced Level Biology and their scores in G.C.E Advanced Level Biology in single and mixed sex schools.

4) There is a predictive validity in the correlation of students' scores in mock G.C.E Advanced Level Biology and their scores in G.C.E Advanced Level Biology in boarding and day schools. 


\section{References}

1) Anderson, L.W., \& Krathwohl, D.R. (Eds). (2001).A Taxonomy for Learning, Teaching and Assessing: A revision of Bloom's Taxonomy of Educational Objectives. New York: Longman. $15 \backslash 10 \backslash 2016$ at $10: 20 \mathrm{am}$.

2) Atkinson, R.C., and Shiffrin, R.M. (1968). Human Memory: A proposed system and its control processes. In K.W Spence and J.T. Spence $\left(1^{\text {st }}\right.$ Edition). The Psychology of Learning and motivation (Vol. 2). San Diego: Academic Press.

3) Bandura, A. (1965). Influence of Models Reinforcement contingencies on the acquisition of imitative responses. Journal of Personality and social Psychology. VOL.1, PAGES 589-596.

4) Bandura, A. (2000). Social Cognitive Theory in A. Kazdin (Ed), Encyclopaedia of Psychology. Washington, DC and New York: American Psychological Association and Oxford University Press.

5) Bearison, D.J., \& Dorval, B. (2002), Collaborative Cognition. Westport, CT: Ablex. In Santrock, J.W (2004). Educational Psychology. New York: McGraw Ill.

6) Case, R. (2000). Conceptual Structure in M. Bennett Developmental Psychology. ( $1^{\text {st }}$ Edition), Philadelphia: Psychology Press.

7) Cele, C.I \& Kwele, M. (2006)." Curriculum change and challenges in Educational Assessment: The Predictive validity for using Regional and international Assessment the Botswana Experience. The Royal Swazisun Convention centre. $28^{\text {th }}$ August $-1^{\text {st }}$ September 2006. Ezuluvini Swaziland. Pp 125- 144.

8) Chauthan, S.S, (1987). Advanced Education Psychology. New Delhi: Educational Books.

9) Cubberley, E.P. Readings in Public Education in the United States. Boston: Houghton Mifflin.

10) Denga, D.L. (1987). Educational Measurement, Continuous Assessment and Psychological Testing. Calabar: Rapid Educational Publishers Ltd.

11) Fafunwa, A.B. (1974).History of Education in Nigeria. London: George Allen and Unwin Ltd

12) Fraenkel, J.R., and Wallen, N.E. (2000). How to Design and Evaluate Research in Education. New York: McGraw-Hill.
13) Fraenkel, J.R., \& Wallen, N.E. (2006). A preliminary investigation into critical thinking skills of Urban High School Students: Role of an IT/STEM - Scientific Research

14) Publishing www.scirp.org/.../reference/ReferencesPapers.asp $\mathrm{x}$ ?ReferenceID...

15) Frieman, J.L. (2002). Learning and Adaptive behaviour. Belmont, C.A: Wadsworth.

16) Hilgard, E.R., Atkinson, R.L., and Atkinson, R.C., (1979). Introduction to Psychology ( $7^{\text {th }}$ Edition). New York: Harcourt Brace Jovanovich, Inc.

17) Jones, N., Kemenes, G., \& Benjamin, P.R. (2001). Selective expression of electrical correlates of differential appetitive classical conditioning in a feedback network. Journal of neurophysiology. Vol. 85, pages 89-97.

18) Liddel, C., Lycett, J. And G., Rae (1997). “ Developmental and Educational psychology". International Journal of Behavioural Development. Psychology Press. Vol. 21, N0 2 of $1^{\text {st }}$ June 1997. Pp. 331 - 348.

19) Maynard, T. (2001). The student teacher and the community of practice: A consideration of "learning as participation" Cambridge Journal of Education. Vol. 31, page 39-52.

20) Mbua, F.N., (1987). Educational and Child Psychology. Yaoundé: Ceper.

21) Merrit, R. (1972). "The Predictive Validity of the American College Test for students from low socio-economic levels". Journal of Educational and Psychological Measurement. 32, N0 2 (Summer 1972. Page 444.)

22) Murray, H.A. (1938). Exploration in Personality. New York: Oxford Press.

23) Musch, J. \& Broder, A. (1999). Test Anxiety versus academic skills: A Comparison of two alternative Models for predicting Performance in statistic examination. Journal of Educational Psychology. Vol. 69 part 1 1999. The British Psychological society pp 105- 116.

24) Nenty, H.J. (2006). "Curriculum change and challenges in Educational Assessment: The predictive validity of public examinations in Africa: A research proposal. 24 ${ }^{\text {th }}$ Annual Conference on association for educational Assessment in Africa. The Royal Swazisun 
Convention centre. $28^{\text {th }}$ August to $1^{\text {st }}$ September 2006. Ezuluvini- Swaziland. Pp. 312-319.

25) Nenty, H.J. (1985). "Fundamentals of Measurement and Evaluation in Education" Unpublished work in the University of CalabarNigeria.

26) Nolan, J.S., \& Jacobson, J. (1972). "The Californian Comprehensive Test of Basic Skills: A predictor of success for High school freshmen". Journal of Education and Psychological Measurement. 32, N0 2 of (Summer 1972) P. 452.

27) Ornstein, A.C. \& Levine, D.U. (1989). Adolescent Delinquency. Boston: Houghton Mifflin Company.

28) Robbins, D. (2001). Vygotsky's PsychologyPhilosophy: A metaphor for Language Theory and Learning. New York: Plenum in Santrock, J.W (2004). Educational Psychology. New York: McGraw Ill.

29) Santrock, J.W (2004). Educational Psychology. New York: McGraw Ill.
30) Ugodulunwa, C.A. and Ugwuanyi, C.L. (1999). Understanding Educational Evaluation (2 Edition). Jos: Deka Publication.

31) Ugwuanyi, C.L. (1991). “ Predictive validity of JME (Joint Matriculation Examination) scores on the scores of some selected University courses" Unpublished Med theses submitted to the Faculty of Education University of Jos- Nigeria.

32) Unwadiae, I. \& Oke, M.G. (2006). Predictive validity of WAEC Scores on university scores. Research in WAEC and its contributions to educational policies and practices in Anglophone West Africa. 24 ${ }^{\text {th }}$ Annual Conference on Association for Educational Assessment in Africa. The Royal Swazi-sun convention centre 2006. Ezuluvini- Swaziland. p.175.

33) WAEC (2001). A Review of studies conducted by Research Division of WAEC 1990-1999. $24^{\text {th }}$ Annual Conference on Association for Educational Assessment in Africa. The Royal Swazisun Convention centre. $28^{\text {th }}$ August to $1^{\text {st }}$ September 2006. Ezuluvini Swaziland. P. 181. 